\title{
Performance enhancement of DC/DC converters for solar powered EV
}

\author{
S. Nagaraj $^{1}$, R. Ranihemamalini ${ }^{2}$, L. Rajaji ${ }^{3}$ \\ ${ }^{1.2}$ Department of Electrical and Electronics Engineering, St. Peter's Institute of Higher Education and Research, India \\ ${ }^{3}$ Department of Electrical and Electronics Engineering, ARM College of Engineering and Technology, India
}

\begin{tabular}{l} 
Article Info \\
\hline Article history: \\
Received Sep 9, 2019 \\
Revised Jan 14, 2020 \\
Accepted Jan 30, 2020 \\
\hline
\end{tabular}

Keywords:

DC/DC converter

Solar panel

Spillage inductance

\begin{abstract}
The paper initially presents the essential drive arrangement required for electric vehicle. It requests high power bidirectional stream ability, with wide info voltage range, and yield voltage of vitality stockpiling gadgets, for example, super capacitors or batteries shift with the adjustment in stack. At that point the tenacity and outline of previously mentioned converter is proposed in this paper. The converter which relates a half extension topology, has high power stream ability and least gadget focuses on that can appropriately interface a super capacitor with the drive prepare of a crossover electric vehicle. Besides, by contrasting the fundamental qualities and applications with some ordinary bidirectional DC/DC converter, the proposed converter has low gadget rating and can be controlled by obligation cycle and stage move. Finally, the most essential attributes of this converter is that it utilizes the transformer spillage inductance as the essential vitality exchange component and control parameters, Simulation waveforms in light of MATLAB recreation are given to exhibit the integrity of this novel topology, and this converter is additionally reasonable for high power application, specifically to control the charge-release of super capacitors or batteries that can be utilized as a part of cross breed solar based electric vehicle.
\end{abstract}

Copyright $@ 2020$ Institute of Advanced Engineering and Science. All rights reserved.

\section{Corresponding Author:}

S. Nagaraj,

Department of Electrical and Electronics Engineering,

St. Peter's Institute of Higher Education and Research,

Chennai, India.

Email: nagarajsubramani11@gmail.com

\section{INTRODUCTION}

In the recent years, solar base HEV (Hybrid Electric Vehicles) has pulled in an ever-rising number of considerations of numerous nations' vehicle industry [1]. Cars fueled by inward burning motors speak to an enormous framework venture, and around 33\% oil utilization $[2,3]$. Therefore, the progress to an all-electric versatile armada has all the earmarks of being extremely alluring and attractive, however it has been restricted by a few key innovation and business issues [4]. Therefore, the change in exploring on Hybrid Vehicles seems, by all accounts, to be alluring. Limited Vehicles have a few favorable circumstances over traditional autos [5,6]. An inverter to drive the engine and DC/DC power converter is placed among the battery and high voltage transport [7]. This chopper must remain operated bi-directionally meanwhile the energy can spill out of the energy storage device to the DC interface or the other way [8,9]. This paper utilizes an illustration that can coordinate with the current gas and power foundation is using module HEV [10]. The generalized block diagram is depicted in Figure 1. In this paper chapter 2 describe the proposed electric vehicle solar based converters requirements. Chapter 3 delineates the simulation circuits and results of proposed work. Finally, it is concluded in Chapter 4. 


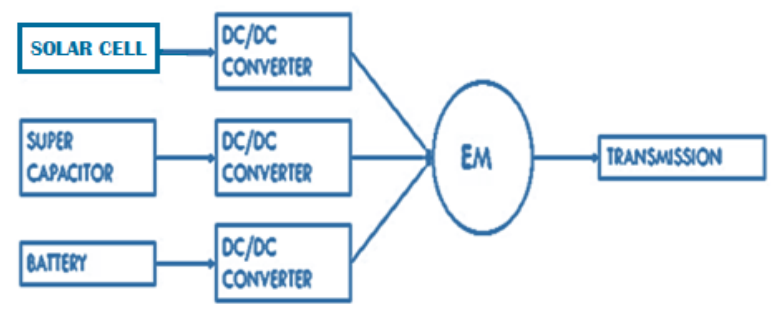

Figure 1. Block diagram

\section{PROPOSED PV BASED ELECTRIC VEHICLE}

In the event of interconnecting the solar panel with the load, the DC/DC power converter is utilized [11]. Wide varieties of DC-DC converter topologies may be available for synchronizing solar cell with the DC - Bus $[12,13]$. However, some outline inspections for EV applications found to be lesser weight, higher efficiency, smaller volume, lower electromagnetically produced interferences, and lower current ripples sucked from the power sources, controlling the bidirectional DC/DC power converters power flow is subjected to the wider range of voltage variation in the input of the converter $[14,15]$. The categories of DC/DC power converters studied and simulated in the proposed work are Boost Converter, full-bridge Converter, Interleaved boost Converter. The performance different performance is analysed namely Inductor Loss, Capacitor Loss, Diode Loss, Switching Los, Total Loss and Efficiency [16, 17].

\subsection{Design and analysis of boost convertor}

A bidirectional power converter generates the DC output voltage that must be larger than the input voltage. It is similar to the switched mode of supplying power with minimum to two semiconductor power switches and a single element of storage device [18]. The output voltage and current is supposed to consists of ripples. A capacitor is utilized as filter for the reduction of ripple content generated in the output voltage [19]. An inductor based filter is provided for reducing the ripples present in the output current. Figure 2 depicts the schematic representation of the converter model with the filters.

Inductor Value is given by (1)

$$
L \geq \frac{V i \times D}{f s \times \Delta I_{l}}
$$

Capacitance Value is given by (2)

$$
C=\frac{I_{o} D}{f s \times \Delta V}
$$

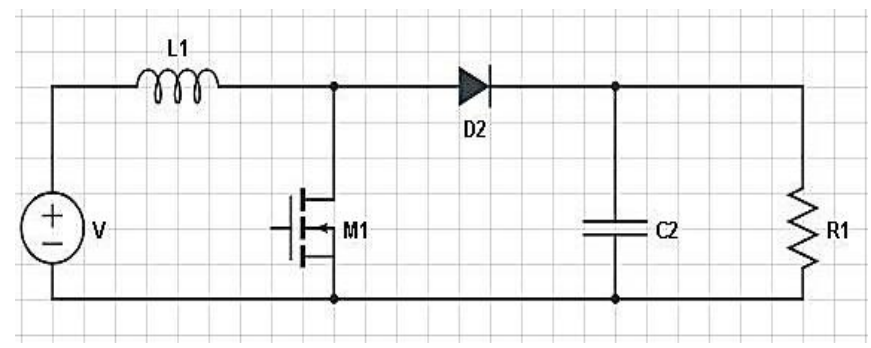

Figure 2. Circuit diagram of boost converter

\subsection{Design and analysis of full-bridge converter}

The configuration of bridge type of DC-DC power converter with four power switches are connected across AC transformer. Converter type called full bridge is one among the commonly utilized structure which provides isolation in the system in addition to stepping up or stepping down the voltage offered in the input side [20]. It also offers many other properties such as reversal of polarities and gives multiple outputs as shown in Figure 3. The three stages of bridge type power converters are: Square wave type, Rectifier network type and Energy transfer network. 
The basic system model comprises of four power switches such as IGBTs, MOSFETs, Thermistors (or) Bipolar transistors and also its accompanying driver circuit systems. The isolated type of bridge power converter consists of a transformer that can provide isolation apart from stepping down or stepping up of voltages [21]. MOSFET type of power semiconductor switches are broadly used for high power rated converters because of its power handling capabilities, simple driver circuits when compared with BJTS.

In general, pair of power switches is involved during one half cycle of the input control signal. Whereas the other pair of power switches is operated during another half cycle of the signal [22]. Pulse width modulated technique is utilized for generating the firing pulses to driving the switches. Switching control signal may be either a square wave or a sine wave. Out of those two square wave is preferred because its simplicity. On the other hand it possesses little higher harmonics content. However, the system with higher frequency of about $20 \mathrm{kHz}$ or above, this can be utilized [23]. Examples for such loads are SMPS, RF heating system etc., that require tuning of filters for minimizing the harmonics effect. For the lower order frequencies like converter fed AC motors are costly and bulky.

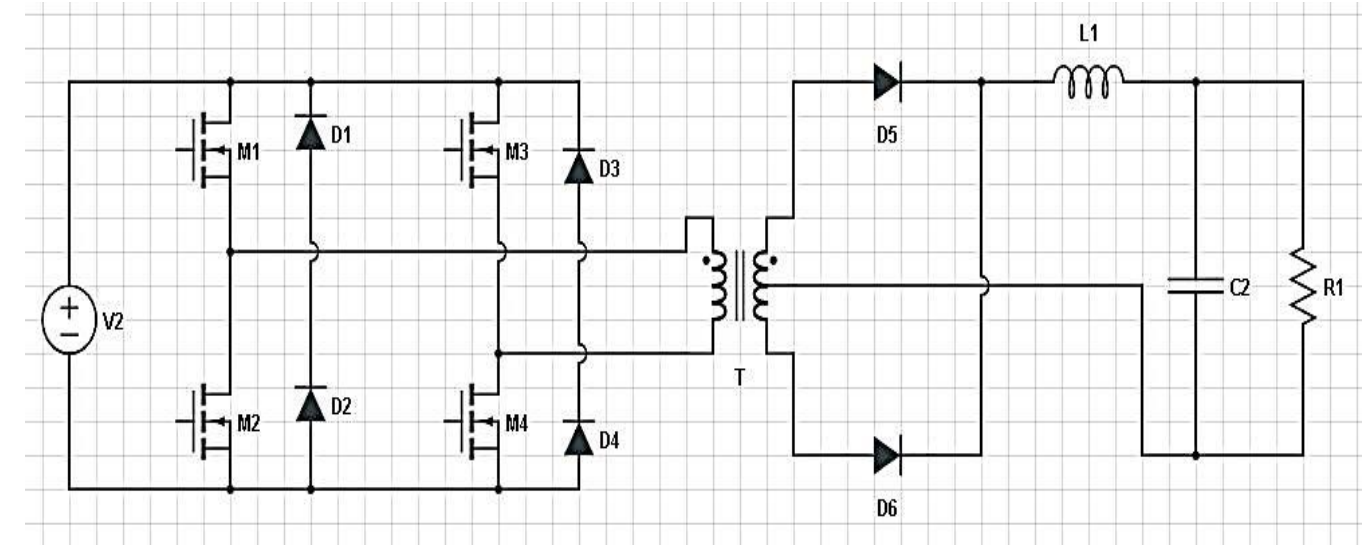

Figure 3. Circuit diagram of full bridge converter

Inductor Value is given by (3)

$$
L=\frac{V i \times D}{2 \times f s \times \Delta I}
$$

Capacitor Value is given by (4)

$$
C=\frac{D \times V_{o}}{(R \times f s) \times \Delta V}
$$

\subsection{Interleaved DC/DC boost converter}

The Interleaved type of DC/DC Boost converter contains two individual DC/DC boost converters coupled in parallel. This type can provide better performance while comparing with conventional DC/DC boost converter. It promised for improved efficiency, decreased size, lesser THD and better reliability. 360/n is the phase shifting difference used for firing the two power switches [24]. Here $n$ denotes the total number of DC/DC boost converters connected in parallel. Figure 4 shows the proposed DC/DC power converter.

The converter under study is functioning in Continuous Conduction Mode, CCM that cause reduced input peak current and conduction loss. Input current of the Interleaved DC/DC Boost power converter be the addition of two inductor currents and has the phase shifted difference of $180^{\circ}$, it leads to decreased input current ripple [25]. Inductor Value is given by (5)

$$
L=\frac{V i \times D}{\Delta I_{p h} \times f s}
$$

Capacitor Value is given by (6) 
$C=\frac{V_{o} \times D}{R \times \Delta V_{o} \times f S}$

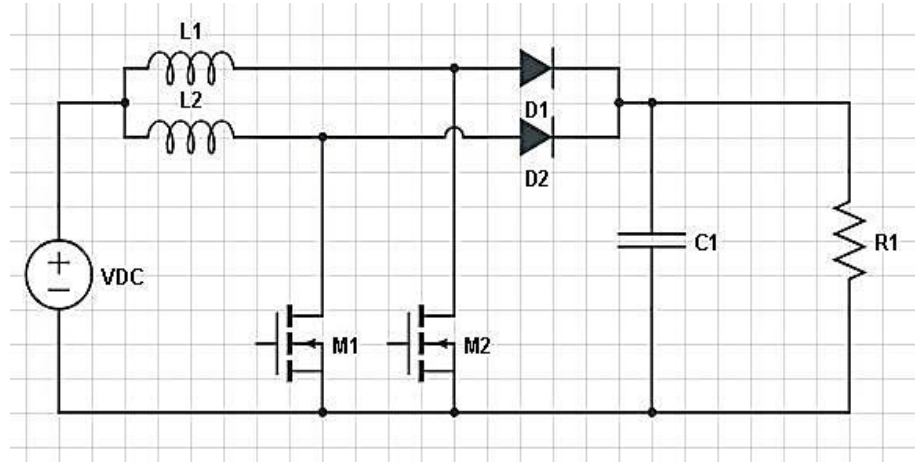

Figure 4. Circuit diagram of interleaved boost converter

\section{RESULTS AND DISCUSSIONS}

The software simulation of proposed solar based interleaved DC/DC boost power converter is shown in Figure 5. An unregulated DC supply voltage is given as the input. DC/DC power converter is used to convert unregulated DC input to controlled DC output. The Interleaved Boost converter comprises of two DC/DC boost power converters that are coupled with each other. The converter uses two MOSFET power switches, two numbers of inductors, two numbers of diodes, single capacitor and resistive load. The solar panel has been designed for the proposed boost converters based on the basic principle of PV panel design. The solar panel design is given by the simulation depicted in Figure 6. The power and current are illustrated in Figures 7 and 8 respectively.

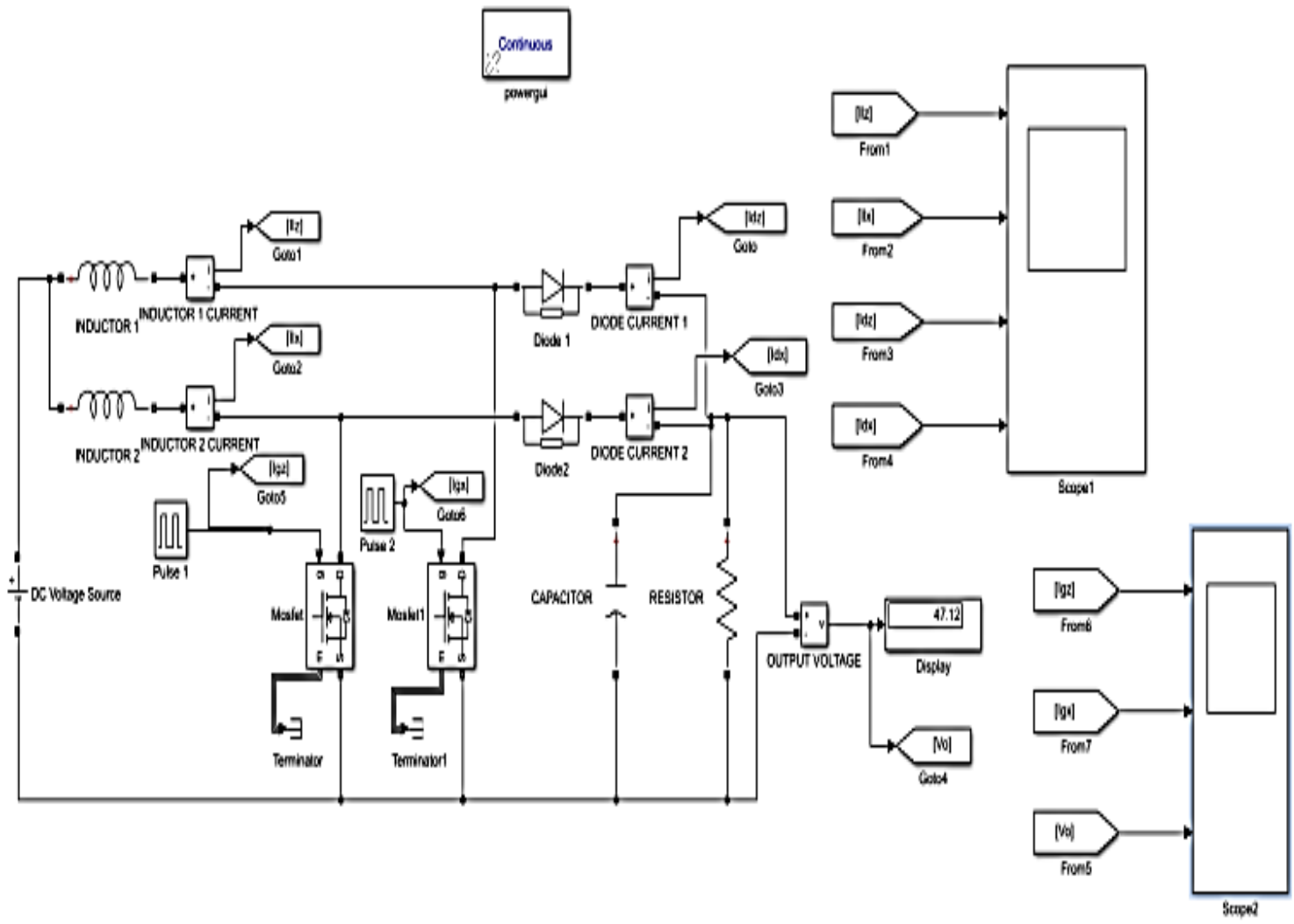

Figure 5. Simulation of interleaved boost converter 


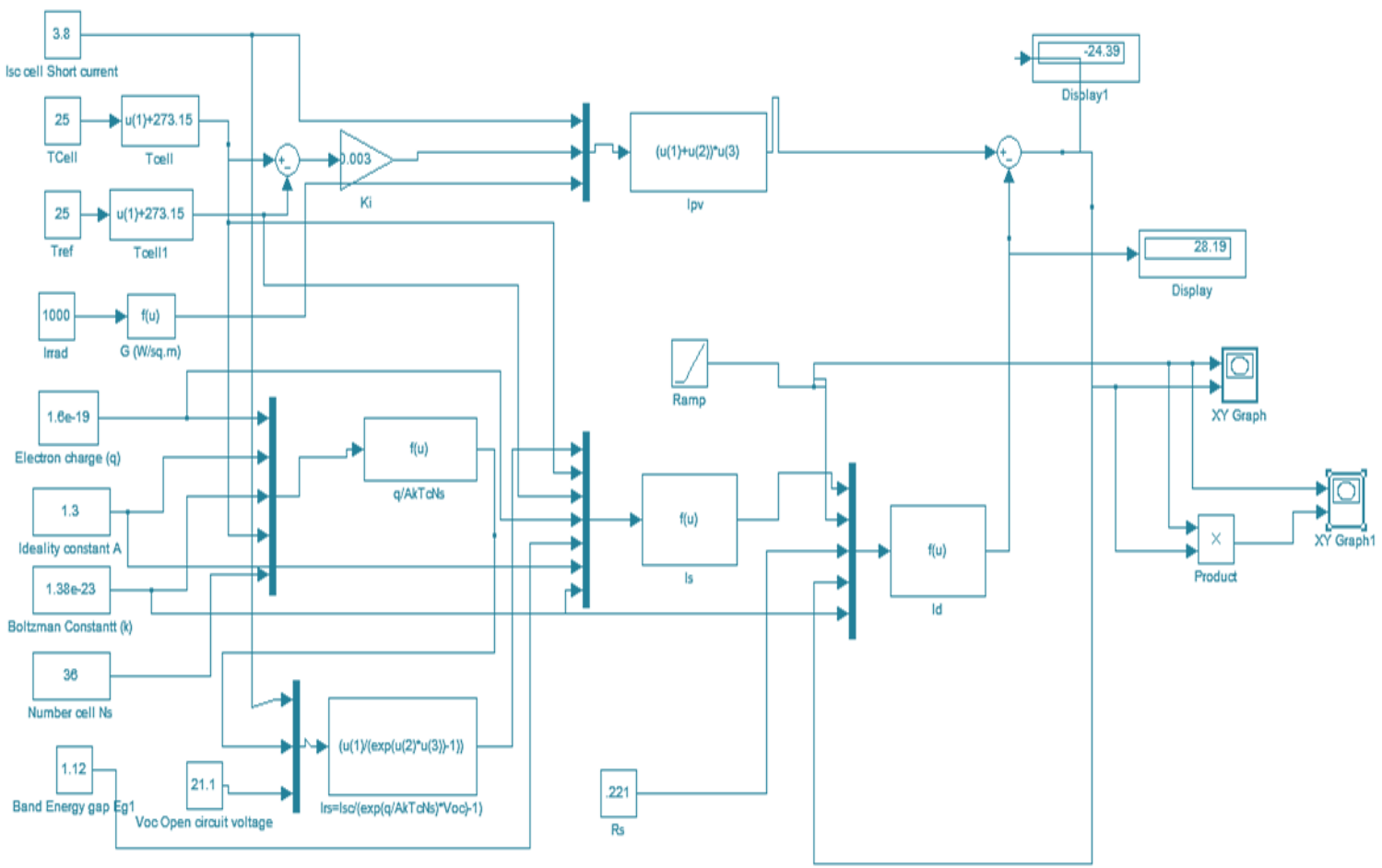

Figure 6. Simulation of solar panel

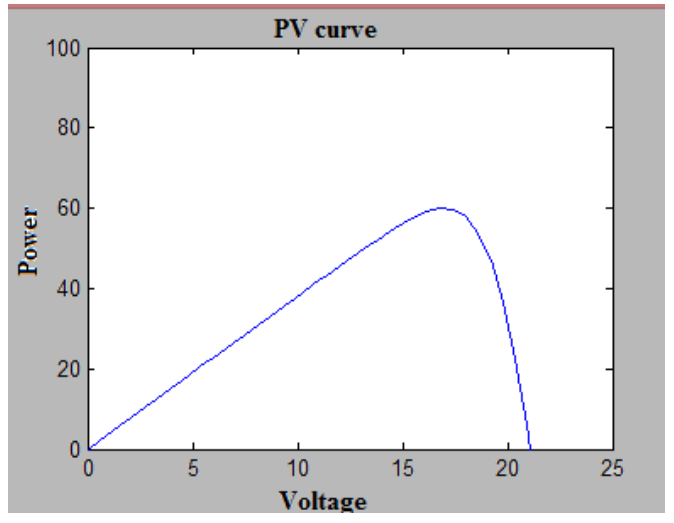

Figure 7. Voltage of solar panel

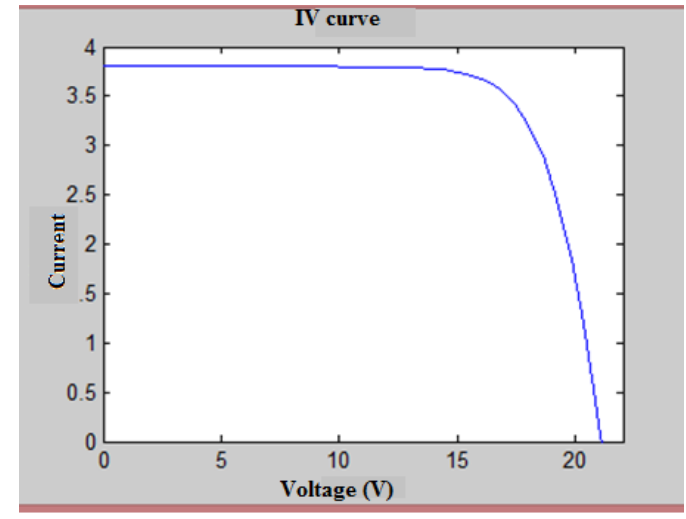

Figure 8. Current of solar panel

$$
\begin{aligned}
& \text { Diode Loss }=V_{d} \times I_{o} \times(1-D) \\
& \text { Switching loss }(P s w)=\frac{\left(t_{1}+t_{2}\right) \times V_{o} \times I_{o}}{2 \times f s} \\
& \text { Conduction Loss }=I_{o}^{2} \times D \times R \\
& \text { Efficincy }=\frac{\text { Output }}{\text { Output }+ \text { Losses }}
\end{aligned}
$$

The simulation of inductor current, diode current and output voltage are described in Figure 9. Starting the diode current is $40 \mathrm{~A}$ in amplitude then from 0.002 seconds to 0.0039 seconds $5 \mathrm{~A}$ current flowing through the circuits, after 0.004 the diode current maintained constant. The output voltage is $50 \mathrm{~V}$ in 
amplitude. The inductor current also high in starting then it is reduced to $10 \mathrm{~A}$. The pulses for the proposed converter are illustrated in Figure 10.

The simulation of full converter transformer output voltage is described in Figure 11. The output voltage is $50 \mathrm{~V}$ in amplitude after the transformer. The inductor current and diode current are illustrated in Figure 12. The simulation of interleaved boost converter output voltage, inductor current, diode current and are described in Figures 13 and 14 respectively. The diode and inductor current are $4 \mathrm{~A}$ in amplitude. Table 1, rephrases the switching losses, inductor losses, diode losses, total losses and efficiency of each converter. It can be noticed that the boost converter has the largest inductor loss among all due to the inductor used. This inductance value can be reduced by increasing the switching frequency of the converter. We can notice that the best entrant for the application is the Interleaving boost topology which has the higher efficiency and lower total losses. We can also notice that efficiency of full bridge is lowest due the high losses calculated. Boost converter is in the middle i.e. its efficiency is greater than full bridge and lower than interleaved similarly goes with losses. The parameters are depicted in Table 2.

Table 1. Parameters of proposed research work

\begin{tabular}{lccccccc}
\hline DC-DC CONVERTER & Vin & $\begin{array}{c}\text { INDUCTOR } \\
\text { (L) }\end{array}$ & $\begin{array}{c}\text { CAPACITOR } \\
(\mathrm{C})\end{array}$ & $\begin{array}{c}\text { RESISTOR } \\
(\mathrm{R})\end{array}$ & $\begin{array}{c}\text { SWITCHING } \\
\text { FREQUENCY } \\
\text { (f) }\end{array}$ & $\begin{array}{c}\text { DUTY } \\
\text { CYCLE } \\
\text { (D) }\end{array}$ & $\begin{array}{c}\text { (Vout) } \\
\text { BOOST }\end{array}$ \\
& $12 \mathrm{~V}$ & $144 \mathrm{e}-6$ & $130 \mathrm{e}-6$ & 23.04 & $25 \mathrm{kHz}$ & 0.75 & 45.1 \\
FULL BRIDGE BOOST & $12 \mathrm{~V}$ & $202 \mathrm{e}-6$ & $50 \mathrm{e}-6$ & 23.04 & $25 \mathrm{kHz}$ & 0.75 & 46.48 \\
INTERLEAVED BOOST & $12 \mathrm{~V}$ & $6.75 \mathrm{e}-3$ & $95 \mathrm{e}-6$ & 23.04 & $2 \mathrm{kHz}$ & 0.75 & 47.24 \\
\hline
\end{tabular}

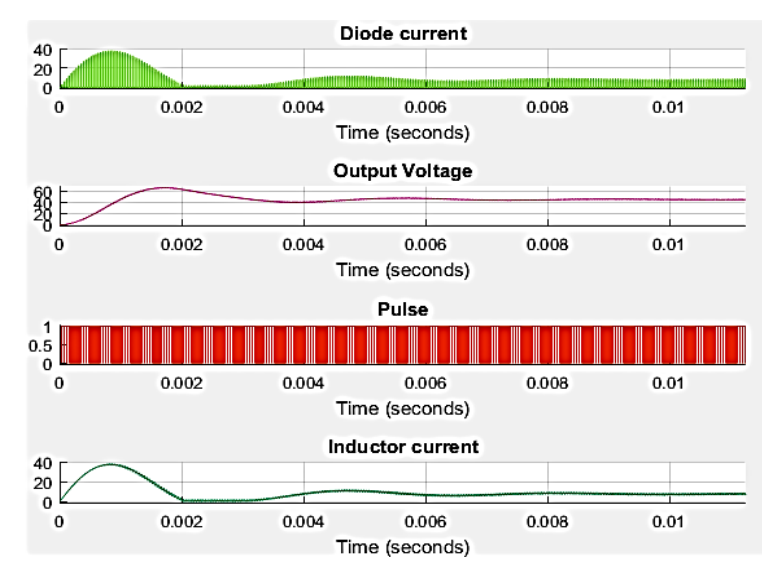

Figure 9. Simulation results graphs of inductor current, diode current, pulse generator, output voltage

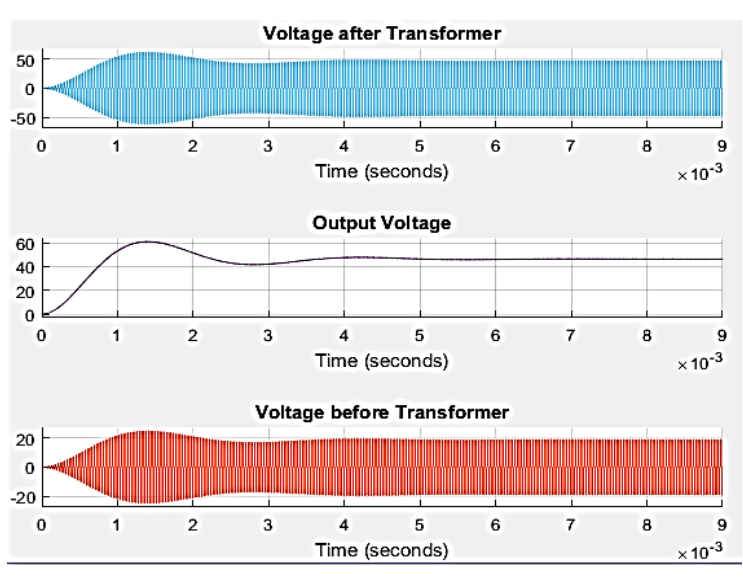

Figure 11. Simulated graphs of primary and secondary sides of transformer, output voltage

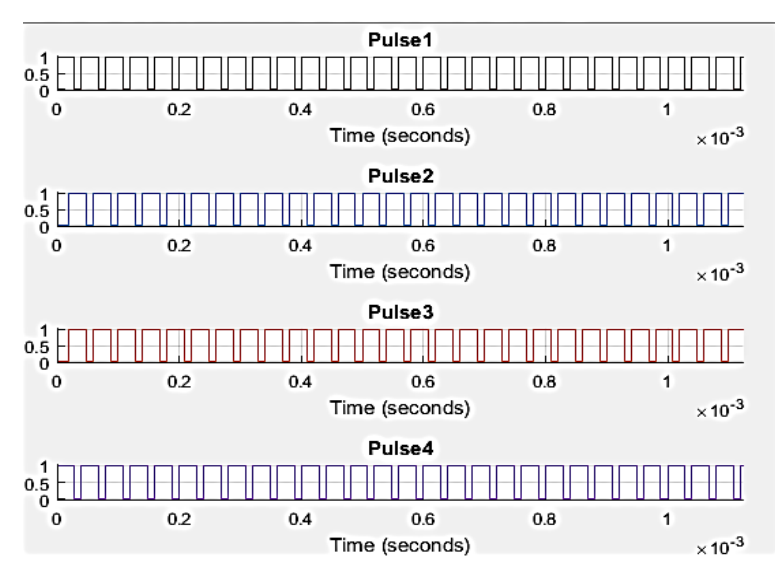

Figure 10. Simulated graphs of pulse generators

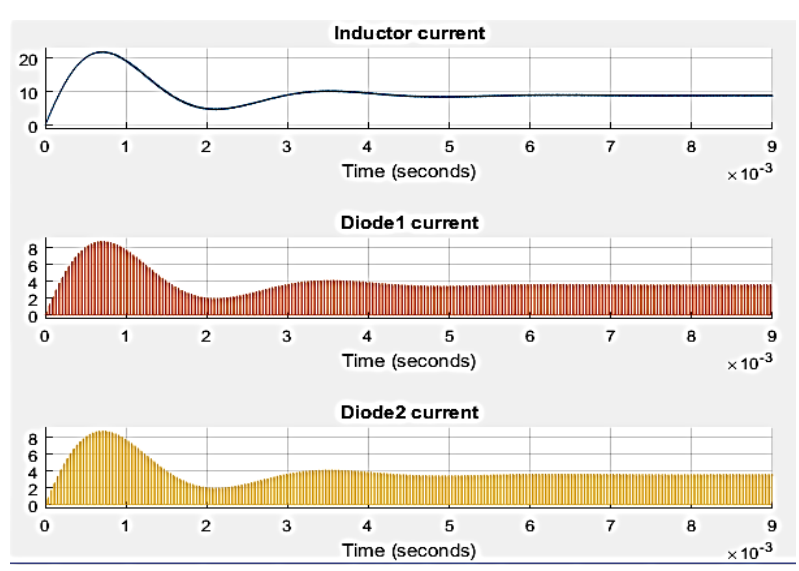

Figure 12. Simulated graphs of inductor current, diode 1 current, diode 2 current 


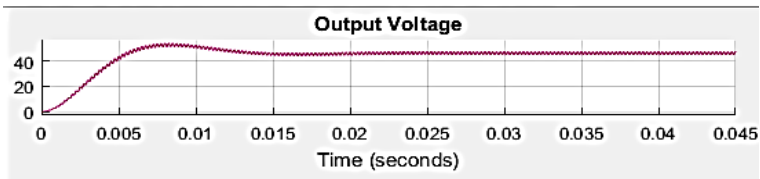

Pulse1

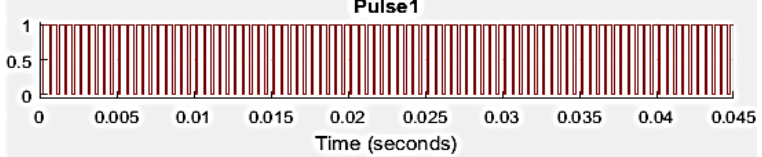

Pulse2

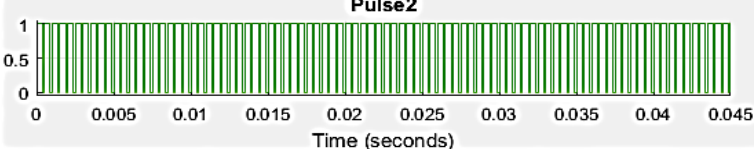

Figure 13. Simulated graphs of output voltage, pulse 1 , pulse 2

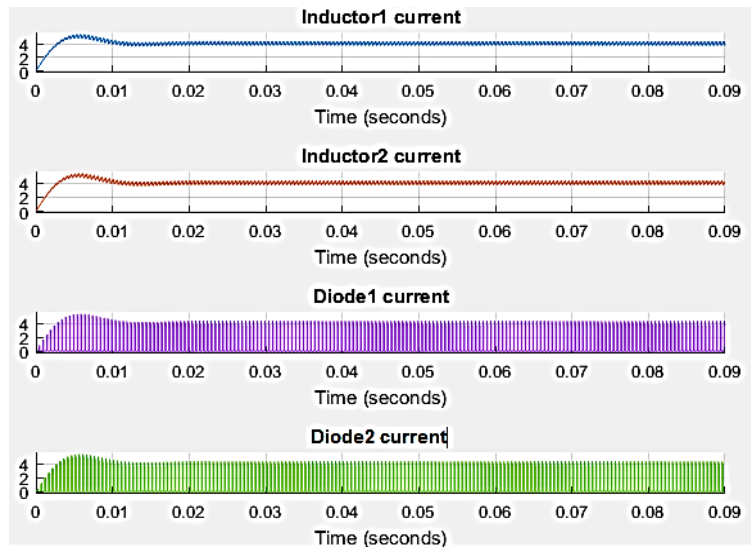

Figure 14. Simulated graphs of inductor 1 current, inductor 2 current, diode 1 current, diode 2 current

Table 2. Performance comparison of different convertets

\begin{tabular}{llllllc}
\hline Converters & $\begin{array}{l}\text { Switching } \\
\text { Loss (W) }\end{array}$ & $\begin{array}{l}\text { Inductor Loss } \\
(\mathrm{W})\end{array}$ & $\begin{array}{l}\text { Conduction } \\
\text { Loss }(\mathrm{W})\end{array}$ & $\begin{array}{l}\text { Diode Loss } \\
(\mathrm{W})\end{array}$ & $\begin{array}{l}\text { Total Losses } \\
(\mathrm{W})\end{array}$ & Efficiency \\
& 3.9 & 2.29 & 0.2869 & 6.5 & 13 & $87.26 \%$ \\
Boost & 4.538 & 1.0185 & 0.0301 & 6.293 & 11.9696 & $88.67 \%$ \\
Full Bridge Boost & 1.9188 & 0.7016 & 0.0310 & 6.273 & 8.9244 & $91.5 \%$ \\
Interleaved Boost & & & & \\
\hline
\end{tabular}

\section{CONCLUSION}

This article comparatively studies the three different types of solar panel based chopper topologies (Bi-directional DC/DC power converter, interleaved converter and Full-bridge converter). Interleave converter enhance the current taken from the solar panel, promised very less power losses and improved output efficiency compared to all other conventional methods. It also has the capability of generating high step up output voltage. Simulations results shows bi-directional solar based interleaved proposed power converter has been a better choice to the PV application.

\section{REFERENCES}

[1] K. Dhineshkumar and C. Subramani, "Kalman Filter Algorithm for Mitigation of Power System," International Journal of Electrical and Computer Engineering (IJECE), vol. 8, no. 2, pp. 771-779, 2018.

[2] Muhammad Ali Raza Anjum., "A New Approach to Adaptive Signal Processing," Indonesian Journal of Electrical Engineering and Informatics (IJEECS), vol. 3, no. 2, pp. 93-108, 2015

[3] Sengamalai, U., Chinnamuthu, S., "An experimental fault analysis and speed control of an induction motor using motor solver," J. Electr. Eng. Technol, vol. 12, pp. 761-768, 2017.

[4] Subotic, I., Bodo, N., Levi, E., "Single-phase on-board integrated battery chargers for EVs based on quinary phase machines," IEEE Trans. Power Electron, vol. 31, pp. 6511-6522, 2016.

[5] Krithika V. and Subramani C., "A comprehensive review on choice of hybrid vehicles and power converters, control strategies for hybrid electric vehicles," Int J. Energy Res., vol. 42, pp. 1789-1812, 2018.

[6] Geetha A. and Subramani C., "A comprehensive review on energy management strategies of hybrid energy storage system for electric vehicles," Int J. Energy Res., vol. 41, pp. 1817-1835, 2017.

[7] Iro Z.S., Subramani C. and Dash S., "A brief review on electrode materials for supercapacitor," Int. J. Electrochem. Sci., vol. 11, pp. 10628-10643, 2016.

[8] Charles I kechukwu Odeh Emeka S. Obe and Olorunfemi Ojo, "Topology for Cascaded Multilevel Inverter," IET Power Electron, vol. 5, no. 4, pp. 1-9, 2016.

[9] Sasan Hashemizadeh Ashan and Mohammad Monfared, "Design and Comparison of Nine-Level Single-phase Inverter with a Pair of Coupled Inductors and Two DC Sources," IET Power Electronics, vol. 9, no. 11, pp. 2271-2281, 2016.

[10] R. Seyezhai and B.L. Mathur, "Analysis, Design and Experimentation of Interleaved Boost Converter for Fuel Cell Power Source," International Journal of Research and Reviews in Information Sciences, vol. 1, no. 2, pp. 2046-6439, Jun. 2011.

[11] J. Srinivas Rao, P. Srinivasa Varma and T. Suresh Kumar, "Novel Switching Design Structure for Three Phase 21Level Multilevel Inverter Fed BLDC Drive Application," International Journal of Power Electronics and Drive System (IJPEDS), vol. 9, no. 3, pp. 1202-1213, 2018. 
[12] Jesus E. Valdez-Recendez, Abraham Claudio-Sanchez, Gerardo V. Guerrero-Ramirez, Carlos Aguilar-Castillo, Alejandro Tapia-Hernandez, Josefa Gordillo-Estrada, "Interleaved High-Gain Boost Converter with Low InputCurrent Ripple For Fuel Cell Electric Vehicle Applications," Proceeding of International Conference on Connected Vehicles and Expo (ICCVE), Las Vegas, USA, pp. 812-817, Dec. 2013.

[13] M. Jang and V. G. Agelidis, "A minimum power-processing-stage fuel -cell energy system based on a boostinverter with a bidirectional backup battery storage," IEEE Trans. Power Electronics, vol. 26, no. 5, pp. 1568-1577, May 2011.

[14] Yi-Ping Hsieh, Jiann-Fuh Chen, Lung-Sheng Yang, Chang-Ying Wu, Wei-Shih Liu, "High-Conversion-Ratio Bidirectional DC-DC Converter with Coupled Inductor," IEEE Transactions on Industrial Electronics, vol. 61, no. 1, pp. 210-222, Jan. 2014.

[15] Prakash G and Subramani C, "Space Vector and Sinusoidal Pulse Width Modulation of Quasi Z-Source Inverter for Photovoltaic System," International Journal of Power Electronics and Drive Systems (IJPEDS), vol. 7, no. 3, pp. 601-609, 2016.

[16] T.F. Wu, Y.C. Chen, J.G. Yang, C.L. kuo, "Isolated bidirectional full-bridge dc-dc converter with a fly back snubber," IEEE Trans. Power Electronics, vol. 25, no. 7, pp. 1915 - 1922, Jul. 2010.

[17] G. Ma, W. Qu, G. Yu, Y. Liu, N. Liang, W. Li, “A zero-voltages witching bidirectional dc-dc converter with state analysis and soft switching- oriented design consideration," IEEE Trans. Industrial Electronics, vol. 56, no. 6, pp. 2174-2184, Jun. 2009.

[18] A.K. Rathore, U.R. Prasanna, "Analysis, design, and experimental results of novel snubber less bidirectional naturally clamped ZCS/ZVS current-fed half-bridge DC/DC converter for fuel cell vehicles," IEEE Trans Industrial Electronic, vol. 60, no. 10, pp. 4482-4491, Oct. 2013.

[19] P. Xuewei, A.K. Rathore, "Novel bidirectional snubber less naturally commutated soft-switching current-fed full-bridge isolated DC/DC converter for fuel cell vehicles," IEEE Trans. Industrial Electronics, vol. 61, no. 5, pp. 2307-2315, May 2014.

[20] Y.S. Lee, Y.Y. Chiu, "Zero-current-switching switched-capacitor bidirectional dc-dc converter," Proceeding of IET Electric Power Applications, vol. 152, no. 6, pp. 1525 - 1530, Nov. 2005.

[21] A. Ajami, H. Ardi, A. Farakhor, "A novel high step-up DC/DC converter based on integrating coupled inductor and switched-capacitor techniques for renewable energy applications," IEEE Trans. Power Electronics, vol. 30, no. 8, pp. 4255 - 4263, Aug. 2015.

[22] Prakash G., C. Subramani, “A low Cost Single Phase Grid Connected Reduced Switch PV Inverter based on Time Frame Switching Scheme," International Journal of Electrical Power and Energy Systems, Elsevier, vol. 77, no. 1, pp. 100-111, 2016.

[23] R.Y. Duan, and J.D. Lee, "High-efficiency bidirectional DC-DC converter with coupled inductor," IET Power Electron, vol. 5, no. 1, pp. 115-123, Jan. 2012.

[24] Usha S. and Subramani C., "Performance Analysis of H-bridge and T-Bridge Multilevel Inverters for Harmonics Reduction," International Journal of Power Electronics and Drive Systems (IJPEDS), vol. 9, no. 1, pp. 231-239, 2018.

[25] Hossein Ardi, Ali Ajami, Faezeh Kardan, Shahla Nikpour Avilagh, "Analysis and Implementation of a Nonisolated Bidirectional DC-DC Converter With High Voltage Gain,” IEEE Trans. on Industrial Electronics, vol. 63, no. 8, pp. 4878-4888, Aug. 2016. 